International Journal of English Literature and Social Sciences
Vol-7, Issue-1; Jan-Feb, 2022
Journal Home Page Available: https://ijels.com/
Journal DOI: $10.22161 /$ ijels

\title{
Victimization of women in Twilight in Delhi
}

Peer-Reviewed Journal

\author{
Behjat Azhar
}

Bahauddin Zakariya University, Multan, Pakistan

Received: 19 Apr 2020; Received in revised form: 19 Jan 2021; Accepted: 25 Jan 2022; Available online: 07 Feb 2022

(C)2022 The Author(s). Published by Infogain Publication. This is an open access article under the CC BY license

(https://creativecommons.org/licenses/by/4.0/).

\begin{abstract}
The research highlights how women are portrayed and objectified in the novel Twilight in Delhi by Ahmed Ali. Women are victimized and suppressed by the men throughout the novel in various ways. This research is carried out by the help of theme of feminism and covers almost all the aspects of the feminist theory. The women are represented as subaltern and under constant influence of patriarchal society. This image of women in the novel is the reflection of whole Indian society, not only of a family or particular group. This article is a minute representation of women before the Partition of the Sub-continent.
\end{abstract}

Keywords - Victimization, women, Twilight in Delhi, feminism, partition.

\section{INTRODUCTION}

Artistic manifestation of life through the medium of language is called literature. On analyzing literature, we can see that by development, trends in literature have been through a sea of changes and there are changes in forms as well as themes. Instead of common emotional themes as were the trends of that time; social and political evils, moods of the age, sexuality, and struggle among different classes of the society for survival became the main themes. This became possible by the contribution of many writers who believe in progress of literature. A Progressive Writers movement started in 1936 to propagate literary cognizance.

There are many writers that have contributed much in the various genres as poetry and fictions in both English and Urdu literature, their contributions are still not acknowledged in the literary world. Among these writers are Syed Sajjad Zahir, Ahmed Ali, Rashid Jehan, and Mahmuduz Zafar. These literery personalities are also known as the initiators and "the trend setters of coming generations of writers". As committed writer and social reformer, Ahmed Ali (1910-1994) holds a very noticeable stance. His contributions have created a very prominent difference in betterment of life.

Being born in Delhi, he received his education from Aligarh and Lucknow universities where he did his masters in English (1931). Ahmed Ali's literary career started with the
Publication of Angaaray (Embers) in 1932, after which he became the founder of All-India Progressive Writer's Movement. Angaaray is a collection of short stories, a rancorous critique of Muslim values. However, he achieved international fame by his first novel Twilight in Delhi (1940). His literary achievement is more substantial in fiction and in poetry as well. Ali earned international acclaim with the publication of his first novel, Twilight in Delhi (1940), which was written in English. He was one of the founders of modern Pakistani English Literature.

The novel Twilight in Delhi is set in Delhi around 1911 to 1919. Ahmed Ali has vividly drawn the picture of old Delhi and its Muslim inhabitants of that era. He depicts the themes of disintegration, degeneration, alienation, gender and social conflicts, nostalgia, the downfall of the Mughal emperors, and the effects of colonialism and imperialism on Indian Muslims in Delhi. The novel deals with the decline and disintegration of Northern India's Muslim aristocracy through the eyes of Mir Nihal and his family. Mehrotra is of the view that the novel is an apt portrayal of the political, cultural and social changes that were an after effect of colonialism in India (2003, p.185).

The central theme of the novel is depicted by the title itself. Twilight in Delhi is the start of a new civilization and the initial stages of colonization of British in the early Twentieth century. It also hints towards the downfall of the 
Muslim society as well as cultures and traditions in India. Set between the moment of change at the end of nineteenth and start of twentieth century, the novel Twilight in Delhi presents a live picture of the decay and loss of an entire civilization and traditional nobility, thus making the history alive once again. The story describes a disseminated household of a typical feudal family of Mir Nihal. The decay and downfall is not only of a Muslim family, but the end of the whole Muslim community.

The story deals with the downfall of Mughal Empire and the family of protagonist, Mir Nihal. With the demolishment of Muslims, the family also loses grip over the Muslim life styles, after the war of 1857.

Twilight refers to the rise of the sun as well as the living standards of living standards of Mir Nihal's family. Towards the end of the novel, twilight in the evening refers the destruction of Mir Nihal's family and overall decline of whole Muslim Mughal Empire. Asghar was a representation of new generation. They have started to mimic the ways of Britishers and were moving away from their own cultural values. The novel also shows the struggles of Mir Nihal as he sticks to older traditions and holds onto his culture and tries to prevent the new generations from adapting to the ways and culture of the British colonizers.

\section{Ahmed Ali's novel articulated distress and concerns over the downfall of Muslim cultures and colonial powers and how they manipulated over the people in sub-continent.}

The book contains many multidimensional themes including; colonialism, imperialism, hybridity, losses, struggle, feminism, male chauvinism, Marxism, superstition, decline and degeneration and few others. In this article, I will focus on one of the main themes of the novel; Feminism. In order to apply feminism on Twilight in Delhi, we will first see what feminism is. The word feminism originated in late 19th century, from French word féminisme.

Feminism is considered as a collection of social and political movements, moral philosophies and common theories that are driven and inspired mostly by the bitter and harsh circumstances experienced by women. Feminism also intends at establishing the legal rights and protection for women. Chandra Mohanty does not think of feminism as a reaction to patriarchy but as "a mode of intervention into particular hegemonic discourses". Marnia Lazreg considers it inappropriate to observe feminism as a singular entity. It is actually the encouragement of rights for equality of both the sexes.

Maggie Humm and Rebecca Walker divided the history of feminism into three waves starting from earlier $19^{\text {th }}$ century till today. The first wave started in $19^{\text {th }}$ century to earlier $20^{\text {th }}$ century, mainly concerned with women suppression and suffrage. The movement to demand legal and social rights for women was called the second wave that started in nineteen sixties and continued till late nineteen seventies. The third wave of feminism continues till present times and started as a reaction to the failures of the first two waves.

\section{Research questions:}

There are some research question that I will try my best to answer in this article;

1. In what ways are women characters victimized by patriarchal oppression and traditional roles in the novel?

2. How are women objectified in the novel?

3. How is purdah manipulated in the novel?

\section{LITERATURE REVIEW}

Due to its brilliant style and subject, Twilight in Delhi had to face a very large amount of criticism. E.M. Forster wrote to Ahmed Ali in a letter, "It is beautifully written and very moving. The detail is almost all of it new to me, and fascinating. It is a sort of poetical chronicle. At the end one has a poignant feeling that poetry and daily life got parted, and will never come together again."

The novel is an epitome of pre-partition period and encompasses all the rituals, culture and people of that time. Anderson gave his critique on the novel saying that the novel is complete in itself as it is about people, time and life. It comments on the people with grace and provides clarity to the plot. It narrows down the gap between the two extremes of that time; the two totally opposite cultures and religions and further paves a path for a narrowed future (1971: p. 86).

Ahmed Ali's book is believed to be full of emotions and colors giving no chance of equality with another book of such caliber. Another critic, Maurice Collis (1940) is of the view that knowledge of a particular religion or nation is not complete and authentic until it comes from the nation itself. We were never familiar with Russia and its culture until we read Turgenev or Tolstoi. Similarly, we can't understand India and its culture unless it is explained by the Indian novelist themselves. Ahmed Ali's novel is at the forefront of such a movement that strives for the acknowledgement.

Many critics and authors discussed about the degeneration of Muslim civilization and culture in this novel. As mentioned by Aslam (2014), "One of the major themes is passing away of Muslim civilization in India. Twilight in Dehli basically shows the decay of the Mughal Kinship and Muslim Civilization." According to Iftikhar, the novel throws light on double standard behaviours of culture 
(2012). Twilight in Delhi provides a real and true picture of the static and decaying culture of Delhi.

To indicate the presence of multiple voices in the novel, Bakhtin (1981) suggested the term social hetroglossia. It means the inculcation of new values into an already existing culture. All around him, Ali saw old traditional values being replaced by new culture. Asghar, Mir Nihal's youngest son was a very fine symbol of such hybridity. "They have lost their historical past, language and culture", mentions Waseem (2015).

The Twilight in Delhi is all about the sufferings and the lives of Muslims suppressed by the British. It is not just about the Muslim people both men and women that were dying and suffering because of the changes but also encompasses the death of a civilization; the death of traditions and the death of culture (Ahmed, 2012). It is just that the women are taken as a symbol to portray the loss. The loss of Muslim empowerment in India was depicted as loss of women and their sufferings. "The condition of the Muslim women was the barometer with which the life of the Indian society could be judged" (Ali, 2000).

Before the partition, the impacts of colonialism were strong yet, they failed to modernize the lives of women in India. There was a wrestling between the reforms and the desire to change, between cultures, traditions and values. The women were influenced by the new traditions but were still deep under the influence of the remnants of conservative Muslim Mughal culture. An example of this was the character of Bilqeece. She used to wear English boots being fascinated by the English women but her attire was still traditional and she never left her head uncovered.

In Twilight in Delhi, Ahmed Ali have very sensitively dealt with the life and frustrations of women of that time. He writes about the unhappiness of Bilqeece who was rejected by her own husband and he also very aptly described the condition and mental trauma of Mehru, Asghar's sister; a helpless girl who as a victim of her own family's viciousness that forced her to marry a disfigured man much older to her, just because her family's research yielded optimistic results for him that were actually false (Shamsie, 2002).

Tradition and culture, through their long surviving institutions and ideologies are a major determinant in the lives of these women. Anuradha Roy identifies this sway of tradition as an aspect of women's experience peculiar to the Indian context. (Roy, 1999; p. 15).

In his article in 2012, Representation of Women in Ali's Twilight in Delhi, Zia Ahmed observed that this task of preserving culture and traditions was now assigned and limited to women just because men have realized that now they are unable to preserve and hold onto their culture, political and traditional values in India.

\section{Theoretical framework:}

I will apply the theory of feminism on various incidents and characters as a tool, in order to highlight the main point of focus. Different underlying meanings are to be revealed with the help of these theories, of apparently simple events happening in the novel.

In Twilight in Delhi, women are depicted as "communal sufferers, familial victims and second class citizens". The dual identity of the Indian Muslim woman - as an Indian and a Muslim -often works to her disadvantage depriving her of the dignity of Islam as a religion sought to safeguard. Islam is persistently portrayed as a misogynistic religion. It puts its women in purdah, confines them to their domestic roles and reduces them to mere bodies sans creativity, sensibility or intellect.

Tradition and culture are two terms that are used to accommodate the lives and experiences of a Muslim woman within feminism. Both these are a major stand point in their lives. Anuradha Roy identifies this sway of tradition as an aspect of women's experience peculiar to the Indian context.

\section{DISCUSSION}

All the female characters of the novel were marginalized and were victims of patriarchy. The head of family, Mir Nihal was a wealthy patriarch with aristocratic habits. Like, he had extramarital affairs and kept mistresses as per the habits of other aristocratic class at that time. The females of the family were kept under strict supervision and they had no say in personal matters such as marriages. They were not allowed to speak for their rights.

Material feminism is a term used to reflect how women are used as commodity. The characters of Babban Jaan and Mushtari Bai makes apparent the objectification of women in the novel. People come to these courtesans to relieve their minds of domestic problems and to satisfy their lust for love. But, there is no one who actually wants to give them respect. They think of them as a time pass and a possession that they buy with money, so there is no place for respect of something that is bought. No one ever marries them. The statement of Mushtari Bai where she thinks of herself as a caravan-serai that where people visit only when needed to be refreshed from their problems of life, shows her helplessness: "I am like a caravan-serai where people come, rest their tired bodies for a while and depart."(Ali (1940) p.76).

At another place, another prostitute Mushtari Bai expresses her distressed emotions as "My life is a dessert in which 
no oasis exists" (Ali (1940), p.76). This statement illustrates her meaningless and colorless life. Zia Ahmed (2012) explains the so called manner full characteristics of the decadents of Mughal Culture by portraying the lust and hunger for the love of women by adding the character of prostitutes in the novel and how they have maintained the society.

In this novel, the infusion of Purdah in a Muslim Woman's life is manipulated by the feudal society to the extent that it became oppression. This oppression of women and purdah was not confined to only this novel, but was very prominent in the sub-continent in the times when British people were trying hard to impart a new culture in the sub-continent. At the beginning of Twilight in Delhi, Ahmed Ali draws a picture of how the women are protected in the four walls of the female portion of the house, Zenana. As he writes, 'Walls stood surrounding them on all sides, shutting the women in from the prying eyes of men, guarding their beauty and virtue' (Ali, 2007, p. 39). All the women in the novel retained Purdah and were confined to the four walls of the house in a separate portion reserved specially for women called 'Zenana'. This was all an act and an effort to maintain Mir Nihal's nobility and a respectable place in society. Begum Jameela (1995) reflected that the pigeons that were kept in a cage by Mir Nihal also symbolized the caged women wasting their whole life sitting and doing nothing in zenana (p. 213).

Ahmed Ali writes in the novel, "The four walls stood high, shutting them all in from the world, protecting them from noise and life" (Ali, p.48). Apparently these words show the care and love for women by the males of their families that they are provided everything in their homes but, these words do not show the care of men for their women but their manipulation of women under the name of 'Purdah'. In actual, they are caged and confined so that they do not demand their rights and resources. At another place in the novel, Ali states that "The world lived and died, things happened, events took place, but all this did not disturb the equanimity of the Zenana," (p. 39). Here it is evident that the female characters of the novel were so caged within the boundaries of home that they had no idea of the outside world nor they had any desire left to leave these four walls to take a stand for themselves or their daughters.

However, on the other hand, both the prostitutes lived a segregated life out of the status of nobility. They were not accepted in the main fold of life. People like Mir Nihal and Asghar as well the other feudalists of the society, would visit them frequently but, they bound their own women in homes. This point outs the double standard behaviors of men.
This double standard of men towards women was not limited to purdah but it stretches over to religion too. The novel presents a picture of deviation of Muslims from Islamic principles. In Quran, it is clearly mentioned that a widow is allowed the right to remarry when her husband dies after a certain period, "When they have fulfilled their term, there is no blame on you if they dispose of themselves in a just and reasonable manner" (The Quran 2.234). But, in earlier times and still today, females were not allowed to remarry. They were forced to live their lives in self-abnegation and an example of this was in the novel itself, as Begum Waheed, Asghar's sister was forced to. Being a widow at the mere age of nineteen, she was also not given the right to marry again because it was against the so- called Indian customs; Indian "social code, derived mostly from prevailing Hindu practices, did not favor a second marriage" (Ali, p.36).

On the other hand, the male society follows no such restrictions as females, for a widower. Most of the time, as soon as the wife dies, males marry again. In the novel too, Asghar is attracted towards his sister-in-law and planned to marry his wife's sister only six months after Bilqeece's death. Another son of Mir Nihal, Shams, also used to flirt with the house maid after his wife died (Dr. Asha S).

Both in colonial and postcolonial literature, women were normally painted as an active agent in the historical and social processes. Similarly in the novel, Ahmed Ali showcased women into both categories having both strong and pathetic characteristics.

"His women characters are mostly strong like Begum Jamal and Begum Waheed, some of them are passive resistors like Begum Nihal's cunning way of having her own way in Asghar's marriage, some of them are symbolic emblem of the postcolonial concept of women as space like Bahadur Shah's relative and the naked woman in street, and all of them epitomize the celebrated indigenous culture which include cultured courtesans like Mushtari Bai” (Riaz).

The female characters were victimized and confined to their traditional roles. They try their best to fulfill the roles defined for them by the society and culture as a wife, mother, sister and daughter. We can see that despite knowing about the extramarital affairs of her husband, Beghum Nihal becomes the source of comfort for the whole family regardless of her mental trauma.

The Traditional roles defined by the society also snatched the basic right from women, their consent in marrying someone of their own will. The right to choose a groom is given in every religion but, still girls "were never consulted about their own marriages and were given away to any man 
their parents selected" (Ali, 1940; p.195). Another victim to this so-called societal traditional roles was Mehro, the younger daughter of the family. She was forced to accept a man much older and disfigured just because her father said so. She was not allowed to question the selection and was not even allowed to see him before the marriage itself. And when she finally had a look at him after the Nikkah, she was devastated. She accepted it as her fate. Her feelings were portrayed beautifully by the writer, "she felt like cow under the butcher's knife. But she could not alter her fate and had to accept it with as much courage as she could muster" (Ali 1940, p.195).

Bilqeece still looks upon her husband as lord and master and even suffers in silence when he grows cold towards her. She accepted his every injustice and oppressive act thinking it as her fate. True to their upbringing, Mehro and Bilqeece uncomplainingly fulfil their roles as passive, selfless and subservient wives.

Psychological feminism is a term used to describe the manipulated women of the novel. The women of Twilight in Dehli are the subaltern voices of the novel. They were suppressed and silenced in every matter. This silence gave rise to dependency on magic and superstitions. All throughout the novel we can see that females were not allowed to speak in any sort of matter. So, in order to overcome this suppression, they frequently visit the fake and real Pirs and used the amulets and charms provided by them to control their households and husbands. These fake Pirs play with the innocent minds and trap them mentally by these charms and amulets. They are oppressed mentally, physically and psychologically by the males and in every relationship.

This whole oppression on women is also played by the women themselves. The novel Twilight in Delhi, is set in a traditional setting where there are separate sections for both men and women. There is no involvement in each other's affairs. In a segregated society, a girl's upbringing and complete socialization is among other women. Somewhat, the mothers are responsible for this. The daughters are brought up in a way to abide by the rules and regulations devised by the males and to follow the traditional values of a Muslim household. They are trained in order to accept everything that comes their way and play a perfect housewife. From a very young age, they are told to behave in a certain way and to obey everything the male members say as a practice to train them for their marital life. In the novel, Bilqeece was such a girl who was trained for her upcoming life by her mother from a very early age, "She had been constantly told that one day she would have to go someone else's home and that she must always behave properly. She was taught the art of cooking and sewing like a perfect house-wife" (Ali 1940). The women of Ali (1940) were reticent and obliging to their men and had no opinion of their own (Zia Ahmed).

This traditional set up caused these women characters to lose a lot of valuable things in their lives. Daughters are taught a way of life by their mother which even if they tried, is not changed with the passage of time. We see that Bilqeece was not able to attract the attention of her husband because Asghar wanted a modern wife. She used to wear English boots due to his insistence but was not able to leave her scarf, because she was not allowed to leave her head uncovered by her mother even in her childhood. She was not able to get rid of this habit and it was the first thing that made her loose her husband's love.

\section{CONCLUSION}

Portrait of women is as silent, reticent and dependent. Females are repressed, violated, marginalized and manipulated at every turn.

Females are of two types in the novel. House wives and dancing girls. Dancing girls are not only part of Indian culture but also ventilators for men who need an outlet of their emotional and physical needs that is fulfilled by these dancing girls. House wives like Begum Nihal are almost blind to the needs of their husbands or like Bilqeece who does not identify the need of her husband $\mathrm{n}$ indulges in selfpity n destroys herself. Purdah was just used by the men for the manipulation of women, to confine them to the four walls of the house well as to hide their own infidelities. Ali mentions that "mostly life (of women) stayed like water in a pond with nothing to break the monotony of the static life" (Ali 1940).

\section{REFERENCES}

[1] Ahmad, Z. (2012). Representation of Women in Ali's Twilight in Delhi (1940). . Int. J. of Res. in Linguistics \& Lexicography: Volume 1, Issue 4.

[2] Ahmed, Z. (2009). Pakistani Feminist Fiction and Empowerment of Women. Pakistaniaat: A Journal of Pakistan Studies. Vol. 1. No. 2.

[3] Ali, A. (1940). Twilight in Delhi. London: Hogarth Press.

[4] Ali, A. (1960). Purple Gold Mountain. London: Keepsake Press.

[5] Ali, A. (1973). Twilight in Delhi. 1940. New Delhi: Oxford UP, Print.

[6] Anderson, D. D. (1971). Ahmed Ali and Twilight in Delhi. Mahfil; Journal of South Asian Literature, 7, 1-2, pp. 81-86.

[7] Begum, J. (1995). "Reconstructing Personal History: The Purdah in Twilight in Delhi and Sunlight on a Broken Column. "Margins of Erasure: Purdah in the Subcontinental Novel in English. Eds. Jasbir Jain and Amina Amin. New Delhi: Sterling, Print. (pp. P 206-15). 
[8] Collis, M. (1940), November 30. Twilight in Delhi. Review. Time and Tide. Time and Tide.

[9] Lazreg, M. (1988). "Feminism and Difference: The Perils of Writing as a Woman on Women in Algeria." Feminist Studies 14.1, (pp. 81-107).

[10] Mehrotra, A. K. (2003). A History of Indian Literature in English. New Delhi: C. Hurst and Co. Publishers.

[11] Mohanty, C. T. (2003). "Under Western Eyes: Feminist Scholarship and Colonial Discourses" Feminist Postcolonial Theory: A Reader. Edinburgh UP,: Ed. Reina Lewis and Sara Mills. Edinburgh.

[12] Riaz, S. (2015). The Image of the Woman Paralleled With the Decline of Delhi. ISSN 1930-2940 15:6.

[13] Roy, A. (1999). Patterns of Feminist Consciousness in Indian Women Writers. New Delhi: Prestige.

[14] Shamsie, M. (2002). "Ahmed Ali" The Literary Encyclopedia.

[15] The Holy Qur-ān: English Translation of the Meanings and Commentary. Ed. The Presidency of Islamic Researches. AlMadinah: Ministry of Hajj and Endowments, (1993). Print 